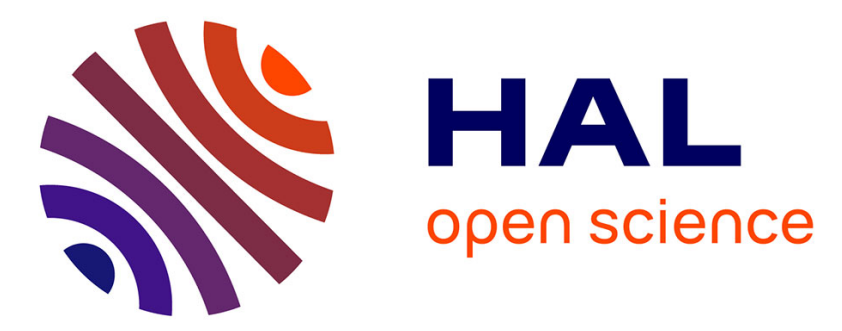

\title{
On the use of trace elements in ancient necropolis studies: Overview and ICP-MS application to the case study of Valdaro site, Italy
}

Cristina Corti, Laura Rampazzi, Ravedoni Cristina, Barbara Giussani

\section{To cite this version:}

Cristina Corti, Laura Rampazzi, Ravedoni Cristina, Barbara Giussani. On the use of trace elements in ancient necropolis studies: Overview and ICP-MS application to the case study of Valdaro site, Italy. Microchemical Journal, 2013, 110, pp.614 - 623. 10.1016/j.microc.2013.07.001 . hal-01704244

\author{
HAL Id: hal-01704244 \\ https://hal.science/hal-01704244
}

Submitted on 8 Feb 2018

HAL is a multi-disciplinary open access archive for the deposit and dissemination of scientific research documents, whether they are published or not. The documents may come from teaching and research institutions in France or abroad, or from public or private research centers.
L'archive ouverte pluridisciplinaire HAL, est destinée au dépôt et à la diffusion de documents scientifiques de niveau recherche, publiés ou non, émanant des établissements d'enseignement et de recherche français ou étrangers, des laboratoires publics ou privés. 


\title{
On the use of trace elements in ancient necropolis studies: Overview and ICP-MS application to the case study of Valdaro site, Italy
}

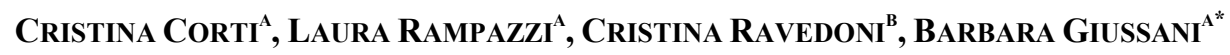 \\ ${ }^{A}$ Department of Science and High Technology, University of Insubria, Via Valleggio 11, 22100 Como, Italy

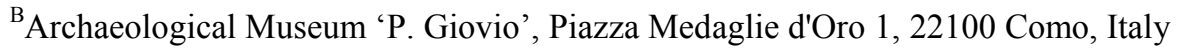 \\ Corresponding author \\ Barbara Giussani, e-mail address: barbara.giussani@uninsubria.it
}

\begin{abstract}
The cross-cutting study of archaeological human remains is an important tool for improving the knowledge of the past civilities. Bones are actually bio-archives, storing information about the lifestyles of the individuals, the place where they lived, the migration habits. In particular, some peculiar trace elements (such as strontium and zinc) are considered indicators of the so-called paleodiet, i.e. whether characterized by vegetables, cereals or meat. A complete overview of the concerning literature is the starting point of this work. A straightforward optimized methodology for the study of ancient bones is proposed coupling for the first time trace element determination by ICP-MS (Mg, Mn, Cu, Zn, Sr and $\mathrm{Pb}$ were investigated) and statistical data analysis. The protocol was applied to samples coming from a necropolis (dated from Neolithic to Bronze Age) found in Northern Italy including 'The Valdaro Lovers', a rare double burial where the two skeletons were facing each other with their arms wrapped around in an enduring embrace. Principal Component Analysis and Discriminant Analysis permitted to correctly classify individuals by the historical period in which they lived according to the archaeological and anthropological information. The results were compared with those found in the literature and a critical discussion on the use of trace metals in this case study is given.
\end{abstract}

KEYWORDS: Prehistoric bones; ICP-MS; Trace elements; Ancient remains; Principal Component Analysis; Linear Discriminant Analysis

\section{INTRODUCTION}

Chemists, archaeologists and anthropologists can cooperate using a multidisciplinary approach in the study of past populations through the examination of findings unearthed in the sites they lived in. Artefacts such as pottery, glassware, weapons, but also mural paintings and architectural elements are investigated from the stylistic and compositional point of view, as they can be the clues for an indirect knowledge of the social and cultural background of prehistoric cultures.

In the last two decades more information has been obtained from the analysis of ancient human remains, that is bones, teeth and hairs. In particular, the analysis of bones contributes to answer questions about social and cultural aspects, working activities, diseases, exposure to poisons, migrations and, above all, dietary habits. Changes in nutritional habits 
reflect, in fact, changes in the human activities, as an example the transformation from hunting-gathering to farming communities.

Bones can be considered bioarchives since their composition includes, apart from hydroxyapatite, collagen and water, elements such as sodium, magnesium, zinc, strontium, barium and lead that have a direct relationship with the diet [13]. These elements enter the body only by ingestion of food, are not subjected to post-mortem alterations and, moreover, could be found in detectable amounts in the skeleton. In particular, tibiae and femurs analyses usually prove very effective as they can fix metals in the lifetime of individuals and give a long-term information $[4,5]$.

Of special interest are strontium, prevalent in vegetables, and zinc, marker of a meat-based diet [6-12]. Strontium varies upon the organism position in the trophic chain with levels getting lower from plants to herbivores and to carnivores, whilst zinc comes from animal products such as meat, eggs and dairies, even if its metabolic pathways are more complex and, in part, still unknown $[8,13,14]$. As an example, according to the model proposed by Beck [6], huntergatherers should eat a greater amount of animal proteins than vegetables, so they show a continuous distribution of zinc levels and a narrower range of strontium ones. On the opposite, farmers should have vegetables-based diets, integrated by variable amounts of wild nuts and animals: their zinc levels are lower and concentrated in a limited range, whilst strontium is more variegated. Strontium and zinc are also good indicators as they are not subjected to post-mortem alterations, i.e. diagenesis including replacement of native ions with others coming from soil [8, 15-18]. Strontium isotope ratios can also be used as a key to trace possible migrations [19-21].

In a multielemental approach, manganese and magnesium (abundant in vegetables) along with copper (meat-based diet indicator) are often also studied, even if they can be subjected to diagenesis [2, 3, 13, 22-27].

The archaeological and anthropological systematic analysis of both bones and the environment where they were recovered (typically necropolis) is fundamental in the study of ancient humans remains. Archaeologists examine the funerary equipment and the stratigraphy of the site. The shape and the raw materials of burial objects help drawing some conclusions about the period and the society to which the tombs belong. Anthropologists participate in the recovery of skeletal remains from the sites and get a closer look at the bones. Pictures and drawings of the remains are taken and the most important data and features useful to reconstruct the taphonomical aspects (position of skeleton or single bones, evident palaeopathological lesions, etc.) are filed. Finally, a number of measurements of the skull, pelvis and peculiar bones are taken in order to make a hypothesis on age, sex, height and weight of the individuals.

This article deals with human skeletons dating from Neolithic to Bronze Age (IX-I millennium B.C.) and brought to light during the excavations in the S. Giorgio Valdaro Necropolis (outskirts of Mantua, Lombardy, Northern Italy). We were asked to classify the individuals from the dietary point of view: we decided to focus on strontium, zinc, manganese, magnesium and copper, diet markers, and on lead, considered a post-mortem contamination marker.

A large number of articles dealing with paleodiet could be found in the literature although only a small number of them go into the details of the analytical methodology. The main drawbacks, if discussed, concern the strong apatite matrix effect, the organic content that could interfere in the analysis and the very low concentrations of the elements [18, 28, 29].

Several techniques were employed to analyse bones: an overview can be found in Table $\mathbf{1}$. 


\begin{tabular}{|l|l|l|}
\hline \multirow{2}{*}{$\begin{array}{l}\text { mineral structure } \\
\text { and organic } \\
\text { content }\end{array}$} & infrared spectroscopy & {$[30-34]$} \\
\cline { 2 - 4 } & X-ray diffraction & {$[7,31-33,35]$} \\
\cline { 2 - 3 } & thermogravimetry & {$[7,36,37]$} \\
\hline \multirow{5}{*}{$\begin{array}{l}\text { quantitative } \\
\text { elemental analysis } \\
\text { techniques }\end{array}$} & $\begin{array}{l}\text { article induced X-ray } \\
\text { and gamma-ray } \\
\text { emission }\end{array}$ & {$[7,28,29,38-48]$} \\
\cline { 2 - 3 } & X-ray fluorescence & {$[17,32,49-52]$} \\
\cline { 2 - 3 } & $\begin{array}{l}\text { neutron activation } \\
\text { analysis }\end{array}$ & {$[7,8,15,35,53]$} \\
\cline { 2 - 4 } & $\begin{array}{l}\text { inductively coupled } \\
\text { mass spectrometry }\end{array}$ & {$[1,7,18,28,42,43,56-63]$} \\
\hline
\end{tabular}

Table 1- Analytical techniques applied to bones

In recent years ICP-MS was frequently used (sometimes associated with laser ablation) for elemental analysis, thanks to its multielemental character, sensitivity, precision and high throughput. For these reasons, we decided to employ ICPMS in this project.

Since this technique requires liquid solutions, solid samples have to be dissolved. A lot of different techniques of solubilisation were found in the literature: an overview can be seen in Table 2

\begin{tabular}{|l|l|l|}
\hline ashing & & {$[1,19,20,25,27,41,42]$} \\
\hline alkaline fusion & & {$[28,64]$} \\
\hline analytes pre-separation & & {$[19-21,57,58,61,63,65]$} \\
\hline \multirow{5}{*}{ acid digestion } & $\mathrm{HNO}_{3}$ & {$[4,18,39,44,56,66-73]$} \\
\cline { 2 - 3 } & ashing $+\mathrm{HNO}_{3}$ & {$[1,19,27,42,62,74,75]$} \\
\cline { 2 - 3 } & $\mathrm{HCl}$ & {$[21,24,76]$} \\
\cline { 2 - 3 } & $\mathrm{HCl}+\mathrm{HNO}_{3}$ & {$[20,25,57]$} \\
\cline { 2 - 3 } & $\mathrm{HClO}_{4}+\mathrm{HNO}_{3}$ & {$[41,77,78]$} \\
\cline { 2 - 3 } & $\mathrm{HF}+\mathrm{HClO}_{4}+\mathrm{HNO}$ & {$[61]$} \\
\cline { 2 - 3 } & $\mathrm{HF}+\mathrm{HNO}_{3}+\mathrm{HCl}$ & {$[28]$} \\
\cline { 2 - 3 } & $\mathrm{H}_{2} \mathrm{SO}_{4}+\mathrm{HNO}_{3}$ & {$[79]$} \\
\cline { 2 - 3 } & $\mathrm{H}_{2} \mathrm{O}_{2}+\mathrm{HNO}_{3}$ & {$[38,80,81]$} \\
\cline { 2 - 3 } & $\mathrm{H}_{2} \mathrm{O}_{2}+\mathrm{HNO}_{3}+\mathrm{HF}$ & {$[28]$} \\
\hline
\end{tabular}

Table 2 - Techniques of solubilisation applied to bones

The dissolution via alkaline fusion was seldom used. This procedure was not considered because solid reagents cannot be easily purified (high contamination risk), high temperatures can cause relevant metals amounts loss and finally the fusion mixtures major elements (e.g. sodium) can form polyatomic species with argon, leading to spectral interferences. The analytes pre-separation was sometimes also carried out to eliminate the strong matrix, but this method is very selective and it generally is used to isolate one single analyte.

The most frequent treatment is by far the acid digestion; $\mathrm{HNO}_{3}$ seems to be one of the most suitable ways to digest bones, but several authors associate it with an ashing step to eliminate the organic components. In this work, ashing treatments were avoided because losses or gains of elements (in particular zinc) can be observed [2, 40, 77, 82]. Other mixtures are also described in the literature (as reported in Table 2).

The use of $\mathrm{HNO}_{3}$ offers several benefits:

a) it simplifies the sample preparation, avoiding contaminations; 
b) it is not necessary to evaporate or strongly dilute the acid prior to the analysis, as required when using $\mathrm{HCl}$, $\mathrm{HClO}_{4}, \mathrm{H}_{2} \mathrm{SO}_{4}$ or HF or mixtures of them;

c) it prevents potential contaminations observed when using $\mathrm{H}_{2} \mathrm{O}_{2}$ : even SupraPure quality additional $\mathrm{H}_{2} \mathrm{O}_{2}$ can be a contaminant for some ultra trace elements [83].

Moreover, $\mathrm{HNO}_{3}$ was reported effective for human tissues if used in conjunction with microwaves without any additional reagent $[39,40,44,67]$. The microwave-assisted digestion permits to obtain a fast and complete dissolution using a reduced acid amount and minimizing the analytes loss and the contamination from open air as the digestion takes place in closed vessels under high pressure.

In this work a methodology based on microwave-assisted digestion using $\mathrm{HNO}_{3}$ was optimized.

In the literature, quantitative analysis by ICP-MS was carried out with various calibration methods, with particular attention to the matrix complexity, as can be seen in Table 3.

\begin{tabular}{|l|l|}
\hline external calibration & {$[1,56,60]$} \\
\hline external calibration + matrix matching & {$[42,56]$} \\
\hline standard additions & {$[29,43,56]$} \\
\hline isotope dilution & {$[56,60]$} \\
\hline internal standard methodology & {$[18,29,43,56,61]$} \\
\hline Table 3 - Calibration methods used in bone analysis
\end{tabular}

Here the authors propose an optimized ICP-MS method with minimum sample pre-treatment and an external calibration quantification strategy. This method was set-up on samples coming from the prehistoric skeletons and validated against NIST SRM 1486 Bone Meal standard reference material.

\subsection{The archaeological background}

S. Giorgio Valdaro is an archaeological area in the outskirts of Mantua (Figure 1), known for some discoveries dating from the Neolithic to the Roman Age and periodically subjected to archaeological investigations [84]. In antiquity the area was crisscrossed by small waterways and the nearby River Po, making it ideal for activities such as hunting, fishing, and agriculture. Neolithic Valdaro possibly was a very developed community, with easy access to strategic trade routes and close ties to neighbouring populations.

In February 2007, archaeologists unearthed 20 single burials and one double burial, as well as the remains of settlement rooms filled with flint tools, including arrow-heads, knives, pottery and animal horns. The burial site was located during the drainage works on the ruins of a I century B.C. Roman villa.

In the past the area was a marshland and possibly the environment helped preserve the skeletons in their near perfect state. The burials were dated from the Neolithic to the Bronze Age (9000-1000 B.C.) on the basis of archaeological observations confirmed by radiocarbon dating [84].

The graves were found in two distinct areas named Section I and Section III.

The individuals of Section III were buried on the bare ground, both in crouching and outstretched position, in some cases with funerary equipment. 8 graves dated back to the Ancient Bronze Age (ABA - 2 male adults, 4 subadults, 2 adults not determined) and 6 graves to the Middle Bronze Age (MBA - 1 male adult, 1 female adult, 4 subadults). It was possible to assess that individuals in the crouching position were more ancient. 


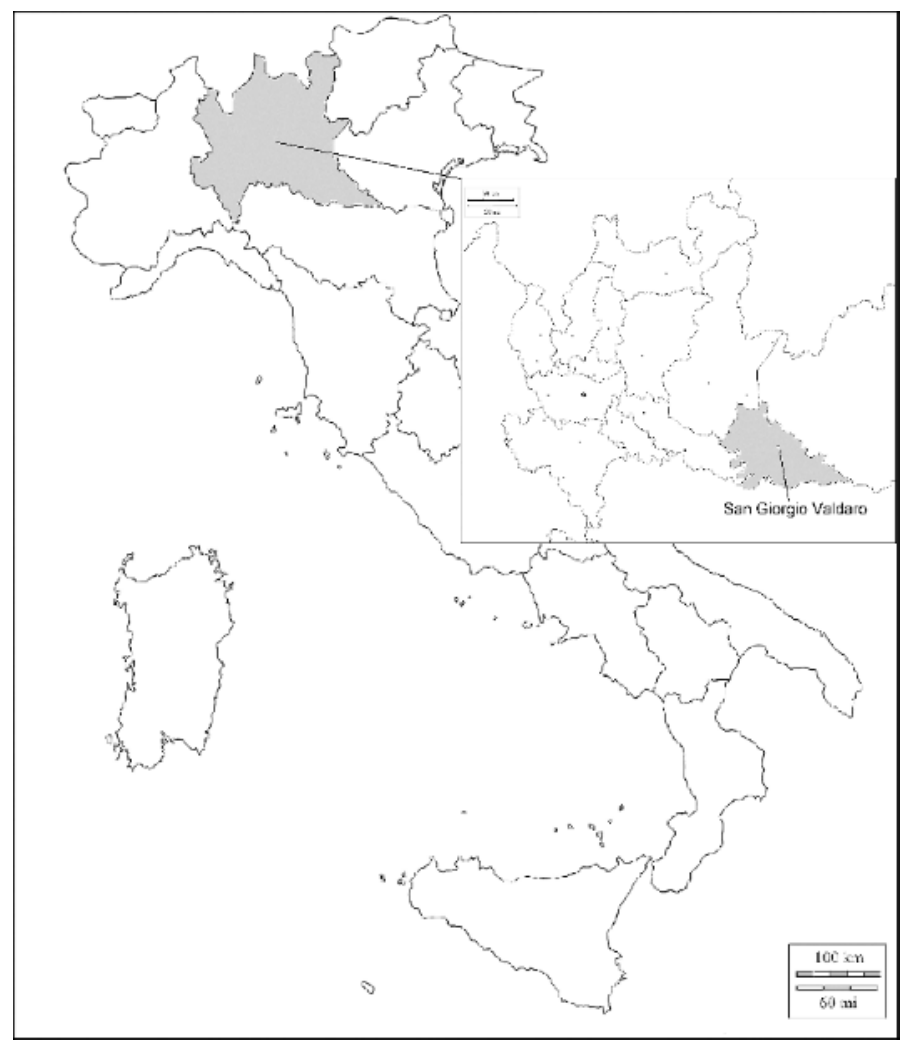

Figure 1 - Location of the investigated necropolis: S. Giorgio Valdaro (Mantua), Lombardy, Northern-Italy

In Section I 7 graves dating to the Late Neolithic (LN) were excavated (5 male adults, 2 female adults, 1 subadult). In all the graves, i.e. a double and 6 single burials, the individuals were laid down in a crouching position on the bare ground.

One of the burials caused an immediate stir among the archaeologists, who were moved by the discovery of a rare double burial: the two skeletons were facing each other with their arms wrapped around in an enduring embrace. The examination of the bones and the intact teeth suggested that the man and the woman were 16-20 years old when they died and around $1.5 \mathrm{~m}$ tall. They were buried North-South, with their heads to the North. The funeral equipment (an arrow-head, a blade, knives, all made of flint) suggested that they were buried during the Neolithic period (5000-4000 $\mathrm{BC})$. The two hugging individuals were called 'The Valdaro lovers' after the location where they were found and became famous as the world's longest known hug. Archaeologists planned to lift with belts the entire block of earth where the couple was buried and sent it to an archaeological laboratory for anthropological and chemical examinations. This burial type is unique, especially for the Neolithic period in which double burials are unheard of, so it represents one of the most remarkable finds in prehistoric archaeology. It is difficult to explain the peculiar burial and to establish the cause of death, whether it was a ritual sacrifice or a sudden death, or lovers who committed suicide together.

Archaeological and anthropological studies on S. Giorgio Valdaro site are still in progress, thus the diet of the individuals is still unknown. No remains of animals were unearthed in the site, so no hypothesis about farming can be proposed. For the same reason it was impossible to use animal bones as reference to standardise the elemental concentrations found in human samples. 


\section{EXPERIMENTAL}

\subsection{Reagents}

Ultrapure water (18M $\Omega$ resistivity, $<5 \mathrm{ppb}$ TOC) from a Milli-Q Gradient A10 system (Millipore) was used for solutions preparation.

Ultrapure $\mathrm{HNO}_{3}$ was produced by sub-boiling distillation in a quartz apparatus (DuoPUR unit from Milestone). Glacial $\mathrm{CH}_{3} \mathrm{COOH}$ (Suprapur grade from Merck) was used during the bone samples cleaning step. $\mathrm{H}_{3} \mathrm{PO}_{4} 85 \%(\mathrm{Carlo}$ Erba Reagenti, Analytical Grade) and acetone (Sigma Aldrich, Chromasolve) were used to prepare the Ionic Chromatography (IC) eluent. A 10mg/l multi-element standard solution (Merck Certipur ICP multi-element standard solution XXI), a 1000mg/l In standard solution and a 100mg/l Ca standard solution (CertiPUR from Merck) were used to prepare standard solutions respectively for ICP-MS and IC quantitative determination. Certified reference material SRM 1486 Bone Meal was purchased from the National Institute of Standards and Technology (NIST - Gaithersburg, MD, USA). A 10mg/l multi-element standard solution (Multi-element Tune A solution, Analytika) was used to optimize the ICP-MS settings.

Solutions preparation and samples manipulation were executed in a Class 100 laminar-flow hood to prevent external contamination. LDPE (low-density polyethylene) sample and reagent bottles and vials were washed and stored in $2 \%$ $\mathrm{HNO}_{3}$ and rinsed with ultrapure water before use.

\subsection{Sampling and sample preparation}

21 individuals were investigated and long bones (tibia and femur) and trabecular bones (ribs) were sampled to compare different skeletal districts from each individual. A total number of 63 samples were thus analyzed.When possible, fragments spontaneously detached from the bones during the excavation were collected; a stainless steel blade was used when necessary.

The samples were treated as follows:

- dry-brushed to remove the soil deposited;

- placed in the ultrasonic bath in clean vessels to remove all the embedded soil particles (three 15 minutes cycles with ultrapure water, replacing water between cycles; one 15 -minutes step with $5 \% \mathrm{CH}_{3} \mathrm{COOH}$ solution);

- left overnight in 5\% $\mathrm{CH}_{3} \mathrm{COOH}$ solution to eliminate the diagenetic soluble carbonates and the first superficial layers, potentially contaminated by contact with soil or metallic tools [7, 19-21, 85];

- rinsed with ultrapure water;

- desiccated in a drying oven at $60^{\circ} \mathrm{C}$;

- stored in pre-cleaned plastic bottles.

Prior to the dissolution they were powdered in an agate mortar and desiccated in a drying oven at $60^{\circ} \mathrm{C}$ until constant weight. As NIST SRM 1486 Bone Meal was purchased in powder form it was dried before dissolution $\left(2 \mathrm{~h}\right.$ at $105^{\circ} \mathrm{C}$ as indicated in the NIST certificate).

A microwave-assisted procedure was optimized to dissolve bone samples and NIST SRM 1486 Bone Meal. Approximately $50 \mathrm{mg}$ of sample were accurately weighed and $2 \mathrm{ml}$ of ultrapure $\mathrm{HNO}_{3} 67.4 \%$ were added.

Vessels were capped and placed in a MLS-1200 MEGA Milestone equipment. The following heating-program was optimized: $3 \mathrm{~min}-250 \mathrm{~W} ; 4 \mathrm{~min}-400 \mathrm{~W} ; 10 \mathrm{~min}-600 \mathrm{~W} ; 20 \mathrm{~min}$ - cooling. A complete dissolution of both samples and NIST SRM 1486 Bone Meal was observed. The resulting solutions were transferred in pre-cleaned LDPE bottles and gravimetrically diluted to $15 \mathrm{ml}$ with ultrapure water. They remained stable during the storage and no precipitation was 
observed. The PTFE vessels were cleaned with $\mathrm{HNO}_{3} 67.4 \%$, using the same heating program prior to any sample dissolution.

\subsection{Trace elements and calcium quantification}

Solutions obtained from the bones dissolution (63 samples) were 1:300 diluted with a solution of $2 \% \mathrm{HNO}_{3}$ in ultrapure water just before the analysis to assure the analytes were within the calibration range and to minimize the matrix effects. An ICP-MS (Thermo Elemental X-Series II), equipped with a Cetac ASX-260 autosampler and a concentric nebulizer, was used for trace elements quantitative determination. Optimization of the instrumental settings was daily performed with a $10 \mu \mathrm{g} / 1$ multi-standard solution, as recommended by the manufacturer: low levels of oxides $\left(\mathrm{CeO}^{+} / \mathrm{Ce}^{+}<2 \%\right)$ and double charged ions $\left(\mathrm{Ba}^{++} / \mathrm{Ba}^{+}<3 \%\right)$ were achieved. Multistandard solutions at $0.1,0.5,1,5$ and $10 \mu \mathrm{g} / 1$ in $2 \% \mathrm{HNO}_{3}$ for external calibration were daily prepared. The following isotopes were measured: ${ }^{24} \mathrm{Mg},{ }^{55} \mathrm{Mn},{ }^{65} \mathrm{Cu},{ }^{66} \mathrm{Zn},{ }^{88} \mathrm{Sr}$ e ${ }^{208} \mathrm{~Pb}$ (the selection of the isotope for every element is a compromise between sensitivity, isotopic abundance and lack of isobaric interferences). ${ }^{115} \mathrm{In}$ at $5 \mu \mathrm{g} / \mathrm{l}$ final concentration was chosen as internal standard.

NIST SRM 1486 Bone Meal was randomly analysed according to the entire procedure (from desiccation to final dilution) together with bone samples, in addition to a procedural blank for every mineralization batch. Check standards were run every 10 samples in the analysis queue.

Solutions obtained from the bones dissolution were 1:300 diluted with ultrapure water and $\mathrm{HNO}_{3}$ was added (final pH=2). A Metrohm 761 Compact IC instrument, equipped with a Metrosep C2 150/4.0 column and a Metrohm 831 Compact Autosampler, was used for calcium analysis. $5 \mathrm{mmol} / 1 \mathrm{H}_{3} \mathrm{PO}_{4}$ was employed as eluent (10ml of acetone/1 eluent were added). The following parameters were employed: injection volume $20 \mu 1$, flow $1 \mathrm{ml} / \mathrm{min}$.

Standard solutions at $1,2,5,8$ and $10 \mathrm{mg} / \mathrm{l}$ in MilliQ and $\mathrm{HNO}_{3}$ (final $\mathrm{pH}=2$ ) were daily prepared for external calibration. Accuracy and precision were evaluated analysing NIST SRM 1486 Bone Meal obtaining the value $26.26 \pm 1.72 \%$ (five aliquots) against the expected value $26.58 \pm 0.24 \%$.

\subsection{Data treatment}

ANOVA $(\alpha=0.05)$ was performed using Microsoft Excel 2007. Principal Component Analysis (PCA) and Linear Discriminant Analysis (LDA - assuming equal prior probabilities) were carried out with the software The Unscrambler $\mathrm{X}$ (CAMO). Prior to any calculation, autoscaling was applied to data to give all the variables the same chance to influence the construction of the PCs. Loading and score plots for the first two principal components were discussed (the other components did not add any relevant information).

\section{RESULTS}

\subsection{Optimized ICP-MS analytical method}

An evidence emerged since the very beginning of this study: the ICP-MS signal was unexpectedly unstable during the analysis, continuously increasing instead of oscillating around a mean value. After 7-10 minutes of analysis (around 1520 instrumental runs-100 sweeps each) it reached a 'steady state'. Considering the average of the last 5 runs (in other words the average of the last 2.5 minutes of analysis) as the 'steady state' value, the initial signal was $15-20 \%$ lower. This trend was observed for all the analytes, both in NIST SRM 1486 Bone Meal and ancient bone samples, in different days and in different positions along the analysis queue. It was then possible to infer that the observed trend was neither due to an instrumental drift in time nor to an influence of a memory effect between samples. Evidence of this behaviour 
could be found in Wolf, 1997 that coped with this problem by introducing a delay before the measurement, considering only the steady state signal [86]. In our opinion this approach is time-consuming, expensive, and requires abundant samples and reagents.

An internal standard strategy was then considered. Examining the literature [18, 29, 43, 61, 87], indium was chosen because it proved to be suitable to normalize the signal for all the analytes of interest, it did not add relevant isobaric interferences and it was not originally present in the samples. Indium was added to every sample at final concentration of $5 \mu \mathrm{g} / \mathrm{l}$, compatible with $\mathrm{Sr}$ and $\mathrm{Zn}$ (the most interesting markers) contents expected in the sample solutions. Signals randomly oscillating around $100 \%$ of the steady state were obtained since the very beginning of the analysis, saving time (around 2.5min per sample) and reagents. External calibration and standard additions methods were evaluated, quantitatively determining the analytes in three ancient bone samples (LN: T2b tibia; ABA: T23 tibia; MBA: T24 tibia). Neither the standard addition curve slopes for all the three samples, nor the standard additions and external calibration ones were statistically different (95\% significance). The quantitative determinations obtained from both methods were in good correlation for all the analytes and all the samples, proving that matrix effects were negligible (data not reported). Thus, the external calibration was confirmed as a suitable quantitative method.

To assure the repeatability of the whole protocol, 250mg of bone (a MBA femur available in a sufficient quantity) were finely ground, homogenized, desiccated until constant weight and then divided into five aliquots and analyzed according to the protocol. No significant differences were observed for all the analytes concentrations (data not reported).

The whole protocol was validated against NIST SRM 1486 Bone Meal for the three certified elements ( $\mathrm{Zn}, \mathrm{Sr}$ and Pb).

Table 4 shows that the measured values (mean of 5 independent analyses) were not statistically different from the expected values, assuring the accuracy of the whole protocol.

\begin{tabular}{|c|c|c|c|}
\hline & $\mathbf{Z n}(\mathbf{m g} / \mathbf{k g})$ & $\mathbf{S r} \mathbf{( m g} / \mathbf{k g})$ & $\mathbf{P b} \mathbf{( m g} / \mathbf{k g})$ \\
\hline Expected & $147 \pm 16$ & $264 \pm 7.0$ & $1.335 \pm 0.014$ \\
\hline Measured & $141 \pm 3.0$ & $265 \pm 3.0$ & $1.4 \pm 0.04$ \\
\hline Recovery\% & 96 & 100 & 105 \\
\hline
\end{tabular}

Table 4 - Measured and expected concentrations for $\mathrm{Zn}, \mathrm{Sr}$ and $\mathrm{Pb}$ with confidence intervals (95\%) together with recovery\%.

Finally, limits of detection (LOD) were determined according to the IUPAC recommendation [88]. They are shown in Table 5 .

\begin{tabular}{|c|c|c|c|c|c|c|}
\hline & Mg & Mn & Cu & Zn & Sr & Pb \\
\hline $\begin{array}{c}\text { LOD liquid } \\
(\boldsymbol{\mu g} / \mathbf{l})\end{array}$ & 0.010 & 0.007 & 0.013 & 0.013 & 0.003 & 0.003 \\
\hline $\begin{array}{c}\text { LOD bones } \\
(\mathbf{m g} / \mathbf{k g})\end{array}$ & 0.89 & 0.59 & 1.18 & 1.18 & 0.30 & 0.30 \\
\hline
\end{tabular}

Table 5 - LOD liquid: LOD in the solutions derived from the digestion; LOD bones: LOD in the solid samples, assuming 50mg of samples were digested. 


\subsection{The case study}

The optimized method was applied to all the fragments of bones coming from the 21 skeletons of the Necropolis. Table 6 summarizes the elements concentration values (mean and range) according to the archaeological classification.

\begin{tabular}{|c|c|c|c|c|c|c|c|}
\hline & & $\mathrm{Mg}(\mathrm{mg} / \mathrm{kg})$ & Mn (mg/kg) & $\begin{array}{l}\mathrm{Cu} \\
(\mathrm{mg} / \mathrm{kg})\end{array}$ & $\begin{array}{l}\mathrm{Zn} \\
(\mathrm{mg} / \mathrm{kg})\end{array}$ & 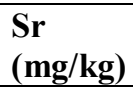 & $\begin{array}{l}\mathrm{Pb} \\
(\mathrm{mg} / \mathrm{kg})\end{array}$ \\
\hline \multirow[t]{8}{*}{$\mathbf{L N}$} & subadults & & & & & & \\
\hline & mean & 591.57 & 11.47 & 6.83 & 138.99 & 242.39 & 3.36 \\
\hline & $\min$ & 576.21 & 8.02 & 5.53 & 81.84 & 228.01 & 2.18 \\
\hline & $\max$ & 621.68 & 16.94 & 9.20 & 175.29 & 265.06 & 4.10 \\
\hline & adults & & & & & & \\
\hline & mean & 593.23 & 59.67 & 47.33 & 130.00 & 200.15 & 6.54 \\
\hline & $\min$ & 424.01 & 0.06 & 13.25 & 55.63 & 108.71 & 1.60 \\
\hline & $\max$ & 964.51 & 201.12 & 104.67 & 283.08 & 254.76 & 11.24 \\
\hline \multirow[t]{8}{*}{ ABA } & subadults & & & & & & \\
\hline & mean & 954.18 & 164.36 & 14.21 & 99.64 & 199.69 & 5.24 \\
\hline & $\min$ & 406.04 & 14.46 & 4.38 & 67.41 & 159.85 & 1.69 \\
\hline & $\max$ & 2278.78 & 496.33 & 36.46 & 145.23 & 245.95 & 11.47 \\
\hline & adults & & & & & & \\
\hline & mean & 628.73 & 41.06 & 15.98 & 164.91 & 232.30 & 3.65 \\
\hline & $\min$ & 266.71 & 19.56 & 10.50 & 75.70 & 188.33 & 2.03 \\
\hline & $\max$ & 842.98 & 104.16 & 32.53 & 303.29 & 264.25 & 6.11 \\
\hline \multirow[t]{8}{*}{ MBA } & subadults & & & & & & \\
\hline & mean & 772.69 & 51.33 & 16.75 & 108.22 & 179.77 & 3.84 \\
\hline & $\min$ & 434.08 & 12.27 & 12.33 & 61.31 & 146.49 & 1.13 \\
\hline & $\max$ & 1588.47 & 124.31 & 18.75 & 332.58 & 260.42 & 5.65 \\
\hline & adults & & & & & & \\
\hline & mean & 745.94 & 215.81 & 16.42 & 225.78 & 297.64 & 5.80 \\
\hline & $\min$ & 568.47 & 99.61 & 12.30 & 160.08 & 258.26 & 2.47 \\
\hline & $\max$ & 917.28 & 368.51 & 26.56 & 266.60 & 363.97 & 9.62 \\
\hline
\end{tabular}

Table 6 - Minimum, maximum and average values for individuals of different age and epoch according to the archaeological classification: LN=Late Neolithic, $\mathrm{ABA}=$ Ancient Bronze Age, MBA=Middle Bronze Age.

Focusing on the results obtained by ICP-MS analysis, a comparison with the literature shows that these values are in agreement with those reported for populations with similar subsistence practices $[3,38,80,89$, 90] and in general with the typical values occurring in human bones [8, 9, 40, 91].

A twofold approach was then followed to analyze the data. ANOVA was carried out to individuate variables that significantly discriminate the individuals and multivariate analysis was employed to consider simultaneously all the investigated chemicals. In particular Principal Component Analysis and Linear Discriminant Analysis were employed as unsupervised and supervised methods respectively on data arranged in a matrix with the bone samples in the rows and the elements concentration values in the columns. 
The score plot obtained by the first PCA model (47\% of the explained variance in the first two PCs - Figure 2), revealed that all the samples belonging to subadults (according to the information given by archaeologists and anthropologists) were grouped in the lower left quadrant (grey dots).
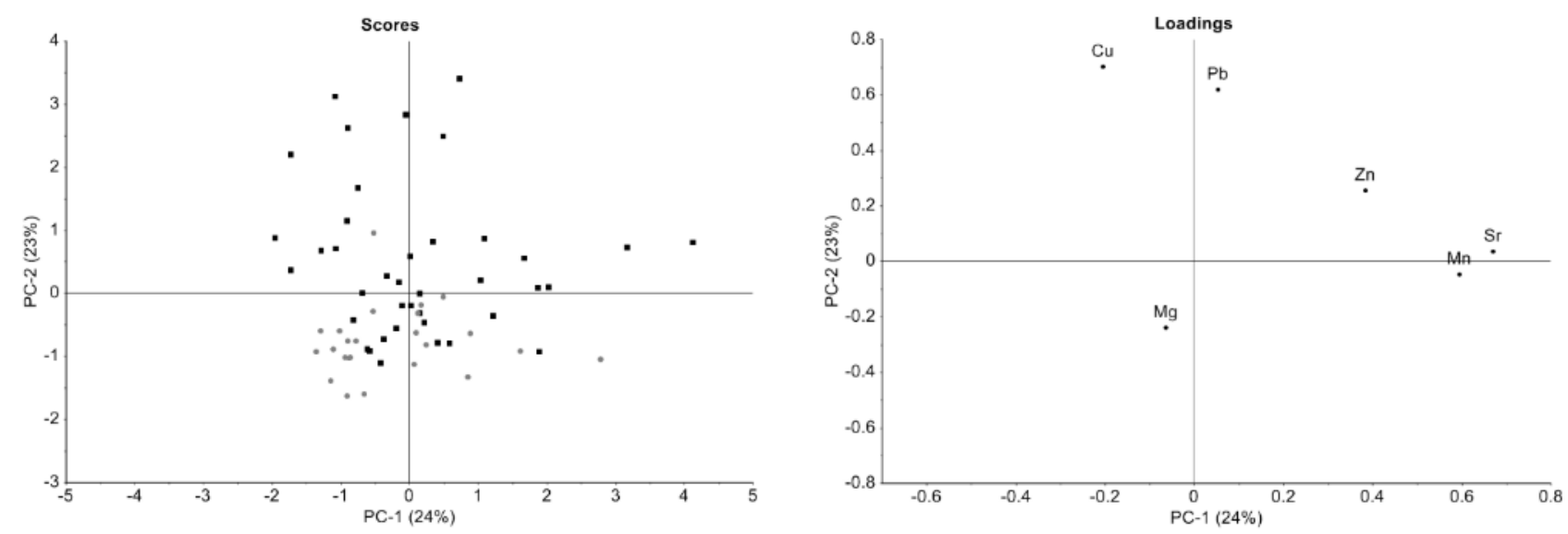

Figure 2 - Score and loading plots for the PCA model using adults and subadults data. subadults=grey dots, adults=black squares

The loading plot showed that they were enriched in $\mathrm{Mg}$ with respect to adult bones and this was confirmed by ANOVA carried out on age (adult/subadult) as the investigated factor $(\mathrm{p}=1.7 \mathrm{E}-03)$ and the $\mathrm{Mg}$ concentration as dependent variable. On the other hand, subadult samples showed the lowest values for all the other investigated elements. In this case, ANOVA found statistically significant differences for $\mathrm{Cu}, \mathrm{Zn}$ and $\mathrm{Sr}$ (p values $\mathrm{Cu}=3.7 \mathrm{E}-04 \mathrm{Zn}=7.8 \mathrm{E}-03, \mathrm{Sr}=1.4 \mathrm{E}-$ 02 respectively). For this reason we decided to investigate separately adults and subadults.

A PCA model was built considering only the adult individuals (36 samples of 12 individuals between 15 and 45 -yearold). Figure 3 shows score and loading plots for the first two components (56\% explained information).
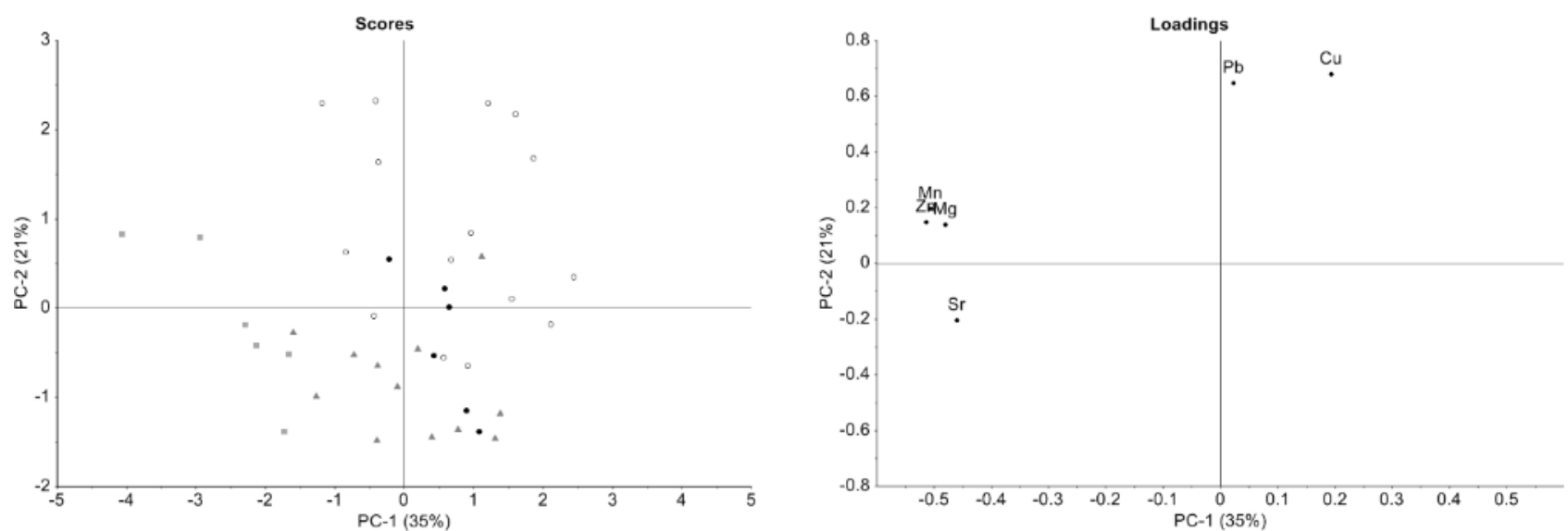

Figure 3 - Score and loading plots for the PCA model using adults' data. Middle Bronze Age=grey squares, Ancient Bronze Age=grey triangles, Late Neolithic $=$ circles, 'The Lovers'=black dots

An interesting information emerged from the score plot, labelling the samples according to the epoch proposed by the archaeologists on the bases of the funerary equipment (MBA=grey squares, $\mathrm{ABA}=$ grey triangles, $\mathrm{LN}=$ circles): samples were well grouped according to the different epochs but one sample belonging to ABA group lied in the upper right quadrant near LN bone samples. This was ascribed to an unexpected high $\mathrm{Pb}$ value probably due to contamination occurred during the sampling or the analysis. It is very interesting to note that bone samples belonging to 'The Lovers' (black dots) partially overlapped the ABA group. 
In the loading plot two different groups of variables could be found. $\mathrm{Mn}, \mathrm{Zn}, \mathrm{Mg}$ and $\mathrm{Sr}$ were important for the construction of $\mathrm{PC} 1$ (high negative loadings) while $\mathrm{Pb}$ and $\mathrm{Cu}$ show high positive loadings on $\mathrm{PC}$. Mn, $\mathrm{Zn}, \mathrm{Mg}$ and $\mathrm{Sr}$ reached the maximum concentration in MBA adult samples: in the case of $\mathrm{Sr}$ and $\mathrm{Mn}$ ANOVA confirmed that these factors were statistically influenced by epoch (MBA/ABA/LN - pSr=2.75E-05, pMn=1.88E-05). LN samples, instead, were enriched in $\mathrm{Pb}$ and $\mathrm{Cu}$. For the latter it was confirmed by ANOVA carried out using epoch as factor and $\mathrm{Cu}$ concentration as dependent variable $(\mathrm{p}=9 \mathrm{E}-04)$.

A good discrimination was obtained also by LDA. The classification model was built assigning each sample to a class, according to the dating proposed by archaeologists. The model correctly classifies $87 \%$ of samples. In particular all samples belonging to ABA group were correctly classified, whilst one sample belonging to MBA group was incorrectly attributed to ABA group. An interesting issue emerged analyzing the results for LN group. Out of 21 samples belonging to 7 individuals, 17 samples were correctly classified whilst 4 samples were attributed to the ABA group. Three of them were collected from 'The Lovers': two samples (femur and tibia) from the female and one sample (femur) from the male.

No differences concerning the sex emerged from the model and this was confirmed by the ANOVA carried out considering sex as factor and elements concentration as dependent variables ( $p$ values $>0.05$ for all the analytes).

The same result was obtained for the bone type.

Concerning the subadults, neither differences between epochs from the PCA model (PC1 31\%, PC2 20\% - data not reported), nor between the type of bones (for subadults the sex is not determined) emerged. Since only one individual belonging to LN epoch was found, ANOVA was carried out using ABA and MBA subadults' data only. Neither difference between epoch nor type of bones was found for all the investigated metals, confirming the results obtained by the PCA model.

\section{IC calcium analysis}

Calcium concentration was then used to normalize the metals' ones, based on the principle that, if diagenesis had occurred, it affected in the same way both calcium matrix and trace metals $[25,26]$. Moreover, calcium was used by some authors to define 'standard ratios' linked to the diet followed by ancient humans [7, 25].

A mean value of $335.37 \pm 35.06 \mathrm{mg} / \mathrm{kg}$ of calcium was found in the 63 samples from the Necropolis: this is coherent with values found in the literature $[3,9,15,92]$. ANOVA was carried out on the Ca data: age was not a discriminant factor $(\mathrm{p}=4.68 \mathrm{E}-01)$.

Considering only adults, epochs (MBA/ABA/LN) did not give statistically significant differences $(\mathrm{p}=5.93 \mathrm{E}-01)$ and the same is true for subadults only. No differences emerged between males and females ( $\mathrm{p}=9.74 \mathrm{E}-01)$. Finally, the skeletal district (ribs, femurs, tibiae) did not influence the concentration of calcium both in adults $(p=1.41 \mathrm{E}-01)$ and in subadults.

Calcium concentration values were then used to normalize the data obtained from ICP-MS analysis and the results are summarized in Table 7. Some authors established reference parameters for these ratios, that resulted compatible with those found in the literature $[25,26]$. 


\begin{tabular}{|c|c|c|c|c|c|c|c|c|}
\hline & & $\mathrm{Ca}(\mathrm{g} / \mathrm{kg})$ & $\mathrm{Mg} / \mathrm{Ca}$ & $\mathrm{Mn} / \mathrm{Ca}$ & $\mathrm{Cu} / \mathrm{Ca}$ & $\mathrm{Zn} / \mathrm{Ca}$ & $\mathrm{Sr} / \mathrm{Ca}$ & $\mathrm{Pb} / \mathrm{Ca}$ \\
\hline \multirow[t]{8}{*}{$\mathbf{L N}$} & subadults & & & & & & & \\
\hline & mean & 329.19 & 1.80 & 0.035 & 0.021 & 0.42 & 0.74 & 0.010 \\
\hline & $\min$ & 321.31 & 1.78 & 0.023 & 0.016 & 0.25 & 0.68 & 0.006 \\
\hline & $\max$ & 341.88 & 1.82 & 0.053 & 0.029 & 0.54 & 0.82 & 0.013 \\
\hline & adults & & & & & & & \\
\hline & mean & 331.73 & 1.86 & 0.186 & 0.150 & 0.43 & 0.61 & 0.020 \\
\hline & $\min$ & 216.84 & 1.06 & 0.000 & 0.039 & 0.14 & 0.35 & 0.005 \\
\hline & $\max$ & 404.87 & 3.64 & 0.615 & 0.400 & 1.44 & 1.04 & 0.051 \\
\hline \multirow[t]{8}{*}{$\mathbf{A B A}$} & subadults & & & & & & & \\
\hline & mean & 352.15 & 2.76 & 0.464 & 0.042 & 0.29 & 0.57 & 0.015 \\
\hline & $\min$ & 317.60 & 1.28 & 0.039 & 0.011 & 0.15 & 0.43 & 0.005 \\
\hline & $\max$ & 436.43 & 6.99 & 1.397 & 0.112 & 0.45 & 0.69 & 0.032 \\
\hline & adults & & & & & & & \\
\hline & mean & 325.41 & 1.94 & 0.127 & 0.050 & 0.63 & 0.72 & 0.011 \\
\hline & $\min$ & 276.01 & 0.79 & 0.060 & 0.033 & 0.23 & 0.51 & 0.006 \\
\hline & $\max$ & 372.21 & 2.73 & 0.340 & 0.106 & 1.63 & 0.95 & 0.019 \\
\hline \multirow[t]{8}{*}{ MBA } & subadults & & & & & & & \\
\hline & mean & 329.01 & 2.38 & 0.157 & 0.051 & 0.33 & 0.55 & 0.012 \\
\hline & $\min$ & 304.46 & 1.29 & 0.040 & 0.038 & 0.20 & 0.42 & 0.003 \\
\hline & $\max$ & 348.24 & 5.19 & 0.388 & 0.058 & 0.98 & 0.78 & 0.018 \\
\hline & adults & & & & & & & \\
\hline & mean & 347.44 & 2.15 & 0.614 & 0.048 & 0.66 & 0.86 & 0.016 \\
\hline & $\min$ & 313.42 & 1.81 & 0.306 & 0.036 & 0.47 & 0.75 & 0.007 \\
\hline & $\max$ & 383.89 & 2.82 & 1.079 & 0.085 & 0.85 & 0.95 & 0.026 \\
\hline
\end{tabular}

Table 7 - Minimum, maximum and average Ca concentration values and element/Ca ratios for individuals of different age and epoch according to the archaeological classification: LN=Late Neolithic, ABA=Ancient Bronze Age, MBA=Middle Bronze Age.

Data were analysed by means of ANOVA and Principal Component Analysis.

ANOVA confirmed that $\mathrm{Mg} / \mathrm{Ca}(\mathrm{p}=4.50 \mathrm{E}-02), \mathrm{Cu} / \mathrm{Ca}(\mathrm{p}=1.00 \mathrm{E}-03), \mathrm{Zn} / \mathrm{Ca}(\mathrm{p}=6.77 \mathrm{E}-03)$ and $\mathrm{Sr} / \mathrm{Ca}(\mathrm{p}=5.67 \mathrm{E}-03)$ distinguish between adults and subadults as expected.

Considering only adult individuals, $\mathrm{Mn} / \mathrm{Ca}(\mathrm{p}=6.37 \mathrm{E}-05), \mathrm{Cu} / \mathrm{Ca}(\mathrm{p}=3.67 \mathrm{E}-03)$ and $\mathrm{Sr} / \mathrm{Ca}(\mathrm{p}=2.36 \mathrm{E}-03)$ could discriminate between epochs, whilst none of the ratios could differentiate skeletal districts or sexs.

For what concerns subadults, Neolithic was excluded because only one individual was found; it can be seen that only $\mathrm{Mn} / \mathrm{Ca}(\mathrm{p}=2.98 \mathrm{E}-02)$ can distinguish between MBA and ABA.

PCA analysis gave results qualitatively very similar to those obtained with metal concentrations: the new model did not add any relevant information.

\section{DISCUSSION}

The statistical treatment of data (metals or metals/Ca) evidenced a clear discrepancy between adults and subadults. Some authors confirmed that Sr levels increase of 50\% from fetal up to age 12 , then changes amount to only about $20 \%$ 
until age 25 , when they begin to remain relatively constant (this is true both for ancient and modern individuals) [6, 10 , 52, 93]. Concerning zinc, Beck reported that it does not fluctuate with age among adults [6], whilst it was found that younger children sometimes have higher levels than older ones [52].

According to the values reported by Giorgi et al. [25], mean values for $\mathrm{Sr} / \mathrm{Ca}$ found in adults from Valdaro corresponded to a vegetables rich diet for all the three epochs.

$\mathrm{Zn} / \mathrm{Ca}$ values pointed to a diet rich in proteins for adults in $\mathrm{ABA}$ and $\mathrm{MBA}$ and to a mixed diet in $\mathrm{LN}$. According to the values proposed by Busetto et al. [7] and based on the data of modern Americans, ABA and MBA adults can be considered as living in a society with a rich economy.

In this study strontium average values were higher than zinc ones: for what concerns Neolithic, it is archaeologically well known that nutrition was generally based mostly on the consumption of vegetables [26]. In particular in Northern Italy the agriculturalist practices began in 5600-5500 B.C., when hunting and gathering were joined with the cultivation of domesticated cereals [94, 95]. Farming began in the middle of the V millennium B.C. with bovine and swine species and became fully established during Bronze Age [94].

Several authors reported an increasing trend of $\mathrm{Sr}$ levels and an opposite trend of $\mathrm{Zn}$ during the transition from huntinggathering to agriculture $[6,10,54]$. It is worthwhile to note that $\mathrm{Sr}$ levels could also be related to the ingestion of molluscs [2, 25, 96]. Giorgi et al. [25] also reported other optimal reference parameters for $\mathrm{Mg} / \mathrm{Ca}$ and $\mathrm{Cu} / \mathrm{Ca}$. Concerning the former, none of our samples reached their value, while for the latter subadults and ABA-MBA adults were far below the range, whilst $\mathrm{LN}$ adults were at the lower limit. It is worthwhile to note that $\mathrm{Cu}$ content in $\mathrm{LN}$ adults resulted higher than ABA-NBA individuals. During Neolithic, farmers had access to legumes to integrate their diet: their consumption, together with offal, could explain the high concentration of copper in Neolithic samples from Valdaro, too. With the advent of Bronze Age, the culture of cereals became definitively preponderant in human subsistence; legumes and fruit were kept as minor dietary resources and this could explain the limited amount of copper found in bones from $\mathrm{ABA}$ and MBA.

Calcium data were examined via ANOVA, evidencing that there were no differences between ages, epochs, sexs or skeletal districts. This is biologically coherent, because it was proved that calcium concentrations are quite constant within the human body and between all the individuals [92]. These results could exclude relevant phenomena of enrichment or depletion due to diagenesis. Keeping in mind that some authors stated that calcium alterations correspond to other metals' ones $[25,26]$, it could be hypothesized that diagenesis did not affect these bones and thus that the observed differences in the content of trace metals could really be bound to distinctions between individuals during life and not after death.

Some authors claimed that bivariate plots $\mathrm{Sr}$ vs. $\mathrm{Zn}$ or $\mathrm{Sr} / \mathrm{Ca}$ vs. $\mathrm{Zn} / \mathrm{Ca}$ can classify individuals according to their diet $[6,92]$. This approach was then applied to Valdaro case study, but it did not give satisfactory results: there were not clear distinctions between epochs.

Bivariate analysis was then replaced by multivariate analysis, using PCA calculation that considers simultaneously all the variables allowing to visualize the results with a very understandable representation.

PCA conducted on adults stressed a clear separation between individuals belonging to different epochs. It was evidenced that $\mathrm{Mn}, \mathrm{Zn}, \mathrm{Mg}$ and $\mathrm{Sr}$ reached the maximum concentration in MBA adults whilst LN samples were enriched mainly in $\mathrm{Cu}$. The same results, as expected, were achieved using the ratios on calcium: it can be seen that this element did not add any information to our classification, but it was useful to compare our data with others found in the literature, as previously shown. The hypothesis here formulated is that of a shift in meat consumption from low valued meat such as offals, rich in copper, to a more refined kind of meat, richer in zinc. 
In conclusion, this approach using trace metals proved to be excellent at classifying the adult individuals from the temporal point of view. Concerning subadults, no differences based on epochs emerged from the data analysis. Bone samples belonging to 'The Lovers' were in a particular situation, because, according to the archaeologists, they belonged to LN, but in the PCA resulted partially overlapped to the ABA group. Their data are reported in Table 8.

\begin{tabular}{|c|c|c|c|c|c|c|c|c|}
\hline & & $\mathrm{Ca}(\mathrm{g} / \mathrm{kg})$ & $\mathrm{Mg} / \mathrm{Ca}$ & $\mathbf{M n} / \mathbf{C a}$ & $\mathrm{Cu} / \mathrm{Ca}$ & $\mathrm{Zn} / \mathrm{Ca}$ & $\mathrm{Sr} / \mathrm{Ca}$ & $\mathrm{Pb} / \mathrm{Ca}$ \\
\hline \multirow{3}{*}{$\mathrm{T} 2 \mathrm{a}$} & mean & 358.14 & 1.42 & 0.139 & 0.047 & 0.21 & 0.59 & 0.015 \\
\hline & $\min$ & 341.65 & 1.26 & 0.078 & 0.036 & 0.18 & 0.53 & 0.008 \\
\hline & $\max$ & 388.42 & 1.54 & 0.195 & 0.053 & 0.26 & 0.66 & 0.019 \\
\hline \multirow{3}{*}{$\mathrm{T} 2 \mathrm{~b}$} & mean & 345.55 & 1.71 & 0.332 & 0.061 & 0.19 & 0.79 & 0.025 \\
\hline & $\min$ & 314.97 & 1.57 & 0.125 & 0.055 & 0.19 & 0.75 & 0.016 \\
\hline & $\max$ & 387.45 & 1.95 & 0.593 & 0.064 & 0.20 & 0.86 & 0.030 \\
\hline \multirow{3}{*}{ together } & mean & 351.84 & 1.56 & 0.235 & 0.054 & 0.20 & 0.69 & 0.020 \\
\hline & $\min$ & 314.97 & 1.26 & 0.078 & 0.036 & 0.18 & 0.53 & 0.008 \\
\hline & $\max$ & 388.42 & 1.95 & 0.593 & 0.064 & 0.26 & 0.86 & 0.030 \\
\hline
\end{tabular}

Unexpectedly low values both for $\mathrm{Cu}$ and $\mathrm{Zn}$ were found, being $18.72 \pm 4.07$ and $71.08 \pm 15.15 \mathrm{mg} / \mathrm{kg}$ respectively their average values ( $\pm 95 \%$ confidence interval). For what concern the ranges of ratio previously cited, according to literature data, their diet could be classified as rich of vegetables, poor in proteins, and far from being optimal in $\mathrm{Mg}$ and $\mathrm{Cu}$.

Can it be hypothesized that their diet was richer in vegetables than the other coeval people, or particularly low in consuming meat?

This same anomaly could be seen in LDA analysis, which correctly classified all samples in ABA, all but one in MBA, and all but four in LN. Three out of these four belonged to 'The Lovers", again, and were attributed to ABA.

\section{CONCLUSIONS}

Ancient remains recovered in Section I and Section III of the Valdaro necropolis were investigated coupling trace metal determination and multivariate analysis. A straightforward analytical methodology was optimized and validated, from the sampling to the data analysis. This methodology required a low amount of sample and proved to be fast, with a high throughput and without interferences.

Trace elements values normalized against calcium contents allowed to gain information concerning the individuals' dietary habits through the comparison with the data found in the literature, but they did not give any information concerning the epoch of the remains, when considered individually.

Multivariate analysis carried out on trace elements values, instead, allowed classifying adult individuals according to the historical period in which they lived, proposed by archaeologists and anthropologists and based on the funerary equipment found in the burials, excluding any diagenetic contribution. In view of future studies, this analysis also gave precious hints about the lack of differences among the different skeletal districts in a same individual and between males and females. At the opposite, it showed the distinction between adults and children. 
In our opinion, this article offers a powerful way to gain information from trace elements when studying past populations with a multidisciplinary point of view.

Peculiarities emerge from the analysis of 'The Lovers', which are surrounded by an air of mystery both from the archaeological and the chemical points of view.

\section{Acknowledgements}

The authors gratefully acknowledge the Soprintendenza Archeologica della Lombardia and the Archaeological Museum 'P. Giovio' (Como), for kindly providing the samples and dr. Marcello Marelli for useful scientific discussions.

\section{REFERENCES}

[1] R. Djingova, B. Zlateva, I. Kuleff, On the possibilities of inductively coupled plasma mass spectrometry for analysis of archaeological bones for reconstruction of paleodiet, Talanta, 63 (2004) 785-789.

[2] L.L. Klepinger, Nutritional assessment from bone, Annual review of anthropology, 13 (1984) 75-96.

[3] J.B. Lambert, C.B. Szpunar, J.E. Buikstra, Chemical analysis of excavated human bone from Middle and Late Woodland sites, Archaeometry, 21 (1979) 115-129.

[4] M.L. Carvalho, A.F. Marques, M.T. Lima, U. Reus, Trace elements distribution and post-mortem intake in human bones from Middle Age by total reflection X-ray fluorescence, in: Spectrochimica Acta Part B, 2004, pp. 1251-1257.

[5] F.D. Pate, J.T. Hutton, K. Norrish, Ionic exchange between soil solution and bone: toward a predictive model, in: Applied Geochemistry, 1989, pp. 303-316.

[6] L.A. Beck, Bivariate analysis of trace elements in bone, Journal of Human Evolution, 14 (1985) 493-502.

[7] M. Busetto, L. Giordani, A. Brandone, C. Cattaneo, A. Mazzucchi, Dietary investigation by trace element content in bones of ancient inhabitants of Northern Italy, in: Journal of Radioanalytical and Nuclear Chemistry, 2008, pp. 355363.

[8] J.F. Farnum, M.D. Glascock, M.K. Sandford, S. Gerritsen, Trace elements in ancient human bone and associated soil using NAA, in: Journal of Radioanalytical and Nuclear Chemistry, 1995, pp. 267-274.

[9] I. Janos, L. Szathmary, E. Nadas, A. Beni, Z. Dinya, E. Mathe, Evaluation of elemental status of ancient human bone samples from Northeastern Hungary dated to the 10th century AD by XRF, Nuclear Instruments \& Methods in Physics Research Section B-Beam Interactions with Materials and Atoms, 269 (2011) 2593-2599.

[10] J.B. Lambert, S.V. Simpson, C.B. Szpunar, J.E. Buikstra, Ancient human diet from inorganic analysis of bone, Accounts of chemical research, 17 (1984) 298-305.

[11] A.L. Rheingold, S. Hues, M.N. Cohen, Strontium and zinc content in bones as an indication of diet, Journal of Chemical Education, 60 (1983) 233-234. 
[12] H. Toots, M.R. Voorhies, Strontium in fossil bones and the reconstruction of food chains, Science, New Series, 149 (1965) 854-855.

[13] R.L. Blakely, L.A. Beck, Trace elements, nutritional status, and social stratification at Etowah, Georgia, Annals of New York Academy of Sciences, 376 (1981) 417-431.

[14] K. Szostek, H. Glab, A. Szczepanek, K. Kaczanowski, Trace element analysis of Bronze Age skeletal and crematory graves from Southern Poland for diet reconstruction, Homo, 53 (2003) 235-246.

[15] M.L. Carvalho, A.F. Marques, Diagenesis evaluation in Middle Ages human bones using EDXRF, X-Ray Spectrometry, 37 (2008) 32-36.

[16] R.E.M. Hedges, Bone diagenesis: An overview of processes, Archaeometry, 44 (2002) 319-328.

[17] G. Quarta, K. Butalag, L. Calcagnile, M. D'Elia, P. Arthur, M. Tinelli, A. Caramia, IBA analyses and lead concentration measurements of AMS-14C dated bones from two medieval sites in Italy, in: Nuclear Instruments and Methods in Physics Research B, 2008, pp. 2343-2347.

[18] M.M. Shafer, M. Siker, J.T. Overdier, P.C. Ramsl, M. Teschler-Nicola, P.M. Farrell, Enhanced methods for assessment of the trace element composition of Iron Age bone, Science of the Total Environment, 401 (2008) 144-161.

[19] R.A. Bentley, R. Krause, T.D. Price, B. Kaufmann, Human mobility at the Early Neolithic settlement of Vaihingen, Germany: evidence from strontium isotope analysis, Archaeometry, 45 (2003) 471-486.

[20] T.D. Price, L. Manzanilla, W.D. Middleton, Immigration and the ancient city of Teotihuacan in Mexico: a study using strontium isotope ratios in human bone and teeth, 27 (2000) 903-913.

[21] N.M. Slovak, A. Paytan, B.A. Wiegand, Reconstructing Middle Horizon mobility patterns on the coast of Peru through strontium isotope analysis, Journal of Archaeological Science, 36 (2009) 157-165.

[22] L.-S.J. Allmäe Raili, Heapost Leiu, Verš Evelin, The content of chemical elements in archaeological human bones as a source of nutrition research, Papers on Anthropology, 21 (2012) 27-49.

[23] J.P. Baraybar, C. De la Rua, Reconstruction of Diet with Trace Elements of Bone at the Chalcolithic Site of Pico Ramos, Basque Country, Spain, Journal of Archaeological Science, 24 (1997) 355-364.

[24] M.V. Dobrovolskaya, Upper Palaeolithic and Late Stone Age human diet, Journal of Physiological Anthropology, 24 (2005) 433-438.

[25] F. Giorgi, F. Bartoli, P. Iacumin, F. Mallegni, Oligoelements and isotopic geochemistry: a multidisciplinary approach to the reconstruction of the paleodiet, Human Evolution, 20 (2005) 55-82.

[26] V. Scattarella, S. Sublimi Saponetti, L. Laraspata, F. Bartoli, F. Bertoldi, The individual of the Early Neolithic of Balsignano (Bari, Italy): a study of some skeletal indicators of stress and palaeonutritional analysis, in: Human Evolution, 2002, pp. 143-155. 
[27] H. Schutkowski, B. Herrmann, F. Wiedemann, H. Bocherens, G. Grupe, Diet, status and decomposition at Weingarten: trace element and isotope analyses on Early Mediaeval skeletal material, Journal of Archaeological Science, 26 (1999) 675-685.

[28] V. Chavagnac, J.A. Milton, D.R.H. Green, J. Breuer, O. Bruguier, D.E. Jacob, T. Jong, G.D. Kamenov, J. Le Huray, Y. Liu, M.R. Palmer, S. Pourtalès, I. Roduhskin, A. Soldati, C.N. Trueman, H. Yuan, Towards the development of a fossil bone geochemical standard: An inter-laboratory study, Analytica Chimica Acta, 599 (2007) 177-190.

[29] K.M. Lee, J. Appleton, M. Cooke, K. Sawicka-Kapusta, M. Damek, Development of a method for the determination of heavy metals in calcified tissues by inductively coupled plasma-mass spectrometry, Fresenius' Journal of Analytical Chemistry, 364 (1999) 245-248.

[30] M. Lebon, I. Reiche, J.-J. Bahain, C. Chadefaux, A.-M. Moigne, F. Fröhlich, F. Sémah, H.P. Schwarcz, C. Falguères, New parameters for the characterization of diagenetic alterations and heat-induced changes of fossil bone mineral using Fourier transform infrared spectrometry, Journal of Archaeological Science, 37 (2010) 2265-2276.

[31] L.M. Miller, V. Vairavamurthy, M.R. Chance, R. Mendelsohn, E.P. Paschalis, F. Betts, A.L. Boskey, In situ analysis of mineral content and crystallinity in bone using infrared micro-spectroscopy of the $v 4$ PO4 3- vibration, Biochimica et Biophysica Acta, 1527 (2001) 11-19.

[32] I. Reiche, L. Favre-Quattropani, C. Vignaud, H. Bocherens, L. Charlet, M. Menu, A multi-analytical study of bone diagenesis: the Neolithic site of bercy (Paris, France), 14 (2003) 1608-1619.

[33] A. Sillen, J.C. Sealy, Diagenesis of Strontium in Fossil Bone: A Reconsideration of Nelson et al. (1986), Journal of Archaeological Science, 22 (1995) 313-320.

[34] T.A. Surovell, M.C. Stiner, Standardizing Infra-red Measures of Bone Mineral Crystallinity: an Experimental Approach, Journal of Archaeological Science, 28 (2001) 633-642.

[35] G. Piga, A. Santos-Cubedo, S. Moya Solà, A. Brunetti, A. Malgosa, S. Enzo, An X-ray Diffraction (XRD) and Xray Fluorescence (XRF) investigation in human and animal fossil bones from Holocene to Middle Triassic, Journal of Archaeological Science, 36 (2009) 1857-1868.

[36] T. Devièse, M.P. Colombini, M. Regert, B.H. Stuart, J.P. Guerbois, TGMS analysis of archaeological bone from burials of the late Roman period, Journal of Thermal Analysis and Calorimetry, 99 (2010) 811-813.

[37] M. Tomassetti, F. Marini, L. Campanella, A. Coppa, Study of modern or ancient collagen and human fossil bones from an archaeological site of middle Nile by thermal analysis and chemometrics, Microchemical Journal, 108 (2013) $7-13$.

[38] M. Arnay-de-la-Rosa, E. Gonzalez-Reimers, Y. Yanes, C.S. Romanek, J.E. Noakes, L. Galindo-Martin, Paleonutritional and paleodietary survey on prehistoric humans from Las Canadas del Teide (Tenerife, Canary Islands) based on chemical and histological analysis of bone, Journal of Archaeological Science, 38 (2011) 884-895.

[39] I. Baranowska, K. Czernicki, R. Aleksandrowicz, The analysis of lead, cadmium, zinc, copper and nickel content in human bones from the Upper Silesian industrial district, The Science of the Total Environment, 159 (1995) 155-162.

[40] H.-W. Kuo, S.-M. Kuo, C.-H. Chou, T.-C. Lee, Determination of 14 elements in Taiwanese bones, The Science of the Total Environment, 255 (2000) 45-54. 
[41] M.J. Martínez-García, J.M. Moreno, J. Moreno-Clavel, N. Vergara, A. García-Sánchez, A. Guillamón, M. Portí, S. Moreno-Grau, Heavy metals in human bones in different historical epochs, Science of the Total Environment, 348 (2005) 51-72.

[42] A.-F. Maurer, M. Gerard, A. Person, I. Barrientos, P. del Carmen Ruiz, V. Darras, C. Durlet, V. Zeitoun, M. Renard, B. Faugère, Intra-skeletal variability in trace elemental content of Precolumbian Chupicuaro human bones: the record of post-mortem alteration and a tool for palaeodietary reconstruction, Journal of Archaeological Science, 38 (2011) 1784-1797.

[43] N.B. Roberts, H.P.J. Walsh, L. Klenerman, S.A. Kelly, T.R. Helliwell, Determination of Elements in Human Femoral Bone Using Inductively Coupled Plasma Atomic Emission Spectrometry and Inductively Coupled Plasma Mass Spectrometry, Journal of Analytical Atomic Spectrometry, 11 (1996) 133-138.

[44] J. Ščančar, R. Milačič, M. Benedik, P. Bukovec, Determination of trace elements and calcium in bone of the human iliac crest by atomic absorption spectrometry, Clinica Chimica Acta, 293 (2000) 187-197.

[45] A.C. Todd, P.J. Parsons, S. Tang, E.L. Moshier, Individual Variability in Human Tibia Lead Concentration, Environmental Health Perspectives, 109 (2001) 1139-1143.

[46] L. Wittmers, A. Aufderheide, G. Rapp, A. Alich, Archaeological contributions of skeletal lead analysis, Accounts of Chemical Research, 35 (2002) 669-675.

[47] N.P. Zaksas, T.T. Sultangazieva, V.A. Gerasimov, Determination of trace elements in bone by two-jet plasma atomic emission spectrometry, Analytical and Bioanalytical Chemistry, 391 (2008) 687-693.

[48] B. Zlateva, R. Djingova, I. Kuleff, On the possibilities of ICP-AES for analysis of archaeological bones, in: Central European Science Journals, 2003, pp. 201-221.

[49] S. Jankuhn, J. Vogt, T. Butz, Determination of the elemental status of ancient human bones from Bockenheim/Rheinland-Pfalz by PIGE and PIXE, Nuclear Instruments and Methods in Physics Research B, 161-163 (2000) 894-897.

[50] I. Reiche, L. Favre-Quattropani, T. Caligaro, J. Salomon, H. Bocherens, L. Charlet, M. Menu, Trace element composition of archaeological bones and post-mortem alteration in the burial environment, in: Nuclear Instruments and Methods in Physics Research B, 1999, pp. 656-662.

[51] D. Spemann, S. Jankuhn, J. Vogt, T. Butz, Ionoluminescence investigations of ancient human bone with an external ion beam, Nuclear Instruments and Methods in Physics Research B, 161-163 (2000) 867-871.

[52] U. Tapper, H. Vuorinen, H. Mussalo-Rauhamaa, Elemental analysis fo long bones of infants from Ficana excavations, Nuclear Instruments and Methods in Physics Research, B49 (1990) 245-249.

[53] D.E.B. Fleming, D.E. Blom, Evidence for lead diagenesis in ancient bones of the Southern Andes, in: Nuclear Instruments and Methods in Physics Research B, 2007, pp. 41-45.

[54] R.K. Harritt, S.C. Radosevich, Results of Instrument Neutron-Activation trace-element analysis of human remains from the Naknek Region, Southwest Alaska, in: American Antiquity, 1992, pp. 288-299. 
[55] V. Zaichick, INAA of $\mathrm{Ca}, \mathrm{Cl}, \mathrm{K}, \mathrm{Mg}, \mathrm{Mn}, \mathrm{Na}, \mathrm{P}$, and $\mathrm{Sr}$ contents in the human cortical and trabecular bone, Journal of Radioanalytical and Nuclear Chemistry, 269 (2006) 653-659.

[56] D.J. Bellis, K.M. Hetter, M.F. Verostek, P. Parsons, Characterization of candidate reference materials for bone lead via interlaboratory study and double isotope dilution mass spectrometry, Journal of Analytical Atomic Spectrometry, 23 (2008) 298-308.

[57] D. De Muynck, C. Cloquet, E. Smits, F.A. de Wolff, G. Quitté, L. Moens, F. Vanhaecke, Lead isotopic analysis of infant bone tissue dating from the Roman era via multicollector ICP - mass spectrometry, Analytical and Bioanalytical Chemistry, 390 (2008) 477-486.

[58] D. De Muynck, C. Cloquet, F. Vanhaecke, Development of a new method for Pb isotopic analysis of archaeological artefacts using single-collector ICP-dynamic reaction cell-MS, Journal of Analytical Atomic Spectrometry, 23 (2008) 62-71.

[59] D. De Muynck, F. Vanhaecke, Development of a method based on inductively coupled plasma-dynamic reaction cell-mass spectrometry for the simultaneous determination of phosphorus, calcium and strontium in bone and dental tissue, Spectrochimica Acta Part B, 64 (2009) 408-415.

[60] K.M. Hetter, D.J. Bellis, C. Geraghty, A.C. Todd, P.J. Parsons, Development of candidate reference materials for the measurement of lead in bone, Analytical and Bioanalytical Chemistry, 391 (2008) 2011-2021.

[61] T.A. Hinners, R. Hughes, P.M. Outridge, W.J. Davis, K. Simon, D.R. Woolard, Interlaboratory comparison of mass spectrometric methods for lead isotopes and trace elements in NIST SRM 1400 Bone Ash, Journal of Analytical Atomic Spectrometry, 13 (1998) 963-970.

[62] K.J. Knudson, B. O’Donnabhain, C. Carver, R. Cleland, T.D. Price, Migration and Viking Dublin: paleomobility and paleodiet through isotopic analyses, Journal of Archaeological Science, 39 (2012) 308-320.

[63] T. Prohaska, C. Latkoczy, G. Schultheis, M. Teschler-Nicola, G. Stingeder, Investigation of Sr isotope ratios in prehistoric human bones and teeth using laser ablation ICP-MS and ICP-MS after Rb/Sr separation, Journal of Analytical Atomic Spectroscopy, 17 (2002) 887-891.

[64] S. Safont, A. Malgosa, M.E. Subirà, G. J., Can Trace Elements in Fossils Provide Information about Palaeodiet?, in: International Journal of Osteoarchaeology, 1998, pp. 23-37.

[65] D. De Muynck, G. Huelga-Suarez, L. Van Heghe, P. Degryse, F. Vanhaecke, Systematic evaluation of a strontiumspecific extraction chromatographic resin for obtaining a purified Sr fraction with quantitative recovery from complex and Ca-rich matrices, Journal of Analytical Atomic Spectrometry, 24 (2009) 1498-1510.

[66] N.W. Bower, S.A. McCants, J.M. Custodio, M.E. Ketterer, S.R. Getty, J.M. Hoffman, Human lead exposure in a late 19th century mental asylum population, Science of the Total Environment, 372 (2007) 463-473.

[67] M. Grotti, M.L. Abelmoschi, S. Dalla Riva, F. Soggia, R. Frache, Determination of lead in bone tissues by axially viewed inductively coupled plasma multichanneled-based emission spectrometry, Analytical Bioanalytical Chemistry, 381 (2005) 1395-1400. 
[68] C. Latkoczy, T. Prohaska, G. Stingeder, M. Teschler-Nicola, Strontium isotope ratio measurements in prehistoric human bone samples by means of high-resolution inductively coupled plasma mass spectrometry (HR-ICP-MS), Journal of Analytical Atomic Spectrometry, 13 (1998) 561-566.

[69] L. Liang, P.C. D'Haese, L.V. Lamberts, M.E. De Broe, Direct calibration for determining aluminum in bone and soft tissues by graphite furnace atomic absorption spectrometry, Clinical Chemistry, 37 (1991) 461-466.

[70] K. Oakberg, T. Levy, P. Smith, A method for skeletal arsenic analysis, applied to the Chalcolithic copper smelting site of Shiqmin, Israel, in: Journal of Archaeological Science, 2000, pp. 895-901.

[71] S. Tang, P.J. Parsons, W. Slavin, Rapid and reliable method for the determination of aluminum in bone by electrothermal atomic absorption spectrometry, The Analyst, 121 (1996) 195-200.

[72] Y. Zhang, Y. Zhang, Y. Tong, S. Qiu, X. Wu, K. Dai, Multi-element determination in cancellous bone of human femoral head by PIXE, Journal of Radioanalytical and Nuclear Chemistry, Letters, 212 (1996) 341-351.

[73] Y.Y. Zong, P.J. Parsons, W. Slavin, Accurate and precise measurements of lead in bone using electrothermal atomic absorption spectrometry with Zeeman-effect background correction, Journal of Analytical Atomic Spectrometry, 11 (1996) 25-30.

[74] K.J. Knudson, T.D. Price, Utility of multiple chemical techniques in archaeological residential mobility studies: case studies from Tiwanaku- and Chiribaya-affiliated sites in the Andes, American Journal of Physical Anthropology, 132 (2007) 25-39.

[75] L.E.J. Wittmers, A.C. Aufderheide, J.G. Pounds, K.W. Jones, J.L.P. Angel, Problems in determination of skeletal lead burden in archaeological samples: an example from the first African Baptist Church population, American Journal of Physical Anthropology, 136 (2008) 379-386.

[76] C. Scarabino, C. Lubritto, A. Proto, M. Rubino, G. Fiengo, F. Marzaioli, I. Passariello, G. Busiello, A. Fortunato, D. Alfano, C. Sabbarese, D. Rogalla, N. De Cesare, A. D'Onofrio, F. Terrasi, Paleodiet characterisation of an etrurian population of Pontecagnano (Italy) by Isotope Ratio Mass Spectrometry (IRMS) and Atomic Absorption Spectrometry (AAS), Isotopes in Environmental and Health Studies, 42 (2006) 151-158.

[77] S. Mays, Bone strontium: calcium ratios and duration of breastfeeding in a Mediaeval skeletal population, Journal of Archaeological Science, 30 (2003) 731-741.

[78] D.A. Nelson, N.J. Sauer, An evaluation of postdepositional changes in the trace element content of human bone, in: American Antiquity, 1984, pp. 141-147.

[79] T. Nakashima, H. Hayashi, H. Tashiro, T. Matsushita, Gender and hierarchical differences in lead-contaminated Japanese bone from the Edo Period, Journal of Occupational Health, 40 (1998) 55-60.

[80] E. González-Reimers, J. Velasco-Vázquez, M. Arnay-de-la-Rosa, F. Santolaria-Fernández, L. Galindo-Martín, Paleonutritional analysis of the pre-Hispanic population from Fuerteventura (Canary Islands), The Science of the Total Environment, 264 (2001) 215-220.

[81] E. González-Reimers, J. Velasco-Vázquez, M. Arnay-de-la-Rosa, V. Alberto-Barroso, L. Galindo-Martín, F. Santolaria-Fernández, Bone cadmium and lead in prehistoric inhabitants and domestic animals from Gran Canaria, The Science of the Total Environment, 301 (2003) 97-103. 
[82] J.B. Edward, R.A. Benfer, J.S. Morris, The effects of dry ashing on the composition of human and animal bone, Biological Trace Element Research, 25 (1990) 219-231.

[83] E. Engström, A. Stenberg, S. Senioukh, R. Edelbro, D.C. Baxter, I. Rodushkin, Multi-elemental characterization of soft biological tissues by inductively coupled plasma-sector field mass spectrometry, Analytica Chimica Acta, 521 (2004) 123-135.

[84] C. Ravedoni, Recovery and multidisciplinary study of skeletons of S. Giorgio Valdaro (Mantova). in: International School of Advanced Studies, University of Camerino (Italy), 2011.

[85] A. Simonetti, M.R. Buzon, R.A. Creaser, In situ elemental and Sr isotope investigation of human tooth enamel by Laser Ablation-(MC)-ICP-MS: successes and pitfalls, Archaeometry, 50 (2008) 371-385.

[86] R.E. Wolf, Analysis of lead $(\mathrm{Pb})$ in antacids and calcium compounds for Proposition 65 compliance, Atomic Spectroscopy, 18 (1997) 169-174.

[87] E.H. Evans, J.J. Giglio, Interferences in Inductively Coupled Plasma Mass Spectrometry. A review., Journal of Analytical Atomic Spectrometry, 8 (1993) 1-18.

[88] L.A. Currie, Nomenclature in evaluation of analytical methods including detection and quantification capabilities (IUPAC recommendations 1995), Pure and Applied Chemistry, 67 (1995) 1699-1723.

[89] J.E. Ericson, D.R. Smith, A.R. Flegal, Skeletal concentrations of lead, cadmium, zinc and silver in ancient NorthAmerican Pecos Indians, Environmental Health Perspectives, 93 (1991) 217-223.

[90] G. Grupe, T.D. Price, P. Schröter, F. Söllner, C.M. Johnson, B.L. Beard, Mobility of Bell Beaker people revealed by strontium isotope ratios of tooth and bone: a study of southern Bavarian skeletal remains, Applied Geochemistry, 12 (1997) 517-525.

[91] J. Zapata, C. Pérez-Sirvent, M.J. Martínez-Sánchez, P. Tovar, Diagenesis, not biogenesis: Two late Roman skeletal examples, in: Science of the Total Environment, 2006, pp. 357-368.

[92] J. Edward, J.M. Fossey, L. Yaffe, Analysis by Neutron Activation of Human Bone from the Hellenistic Cemetery at Asine, Greece, in: Journal of Field Archaeology, 1984, pp. 37-46.

[93] E.M. Sowden, S.R. Stitch, Trace elements in human tissue. 2. Estimation of the concentrations of stable strontium and barium in human bone, The Biochemical journal, 67 (1957) 104-109.

[94] C. Malone, The Italian Neolithic: A synthesis of research, Journal of World Prehistory, 17 (2003) 235-312.

[95] M. Rottoli, E. Castiglioni, Prehistory of plant growing and collecting in northern Italy, based on seed remains from the early Neolithic to the Chalcolithic (c. 5600-2100 cal B. C.), Vegetation History and Archaeobotany, 18 (2009) 91103 .

[96] M.J. Schoeninger, C.S. Peebles, Effects of mollusc eating on human bone strontium levels, Journal of Archaeological Science, 8 (1981) 391-397. 